$$
\text { DOE/PC/90304- TH }
$$

DOE/PC/90304--T4

DE93 006478

$$
\text { DE-FG-22-90PC90304 }
$$

\title{
SELECTIVE SOLVENT ABSORPTION IN COAL CONVERSION
}

$$
\begin{aligned}
& \text { Quarterly Report for the Period } \\
& \text { April 1, } 1992 \text { to June 30, } 1992
\end{aligned}
$$

John W. Larsen and Jewel Amui

JAN 291993

$$
\begin{gathered}
\text { Department of Chemistry } \\
\text { Lehigh University }
\end{gathered}
$$

Bethlehem, Pennsylvania 18015

June 1992
PREPARED FOR THE UNITED STATES DEPARTMENT OF ENERGY Under contract DE-FG-22-90PC90304

$\underline{1}$

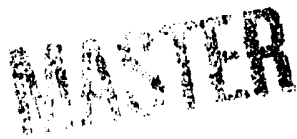




\section{objectives:}

1. To determine the importance of the presence of added hydrogen donor compounds within the coal in the first stage of direct liquefaction processes.

2. To determine the composition of the solvent absorbed by and present within the coal in the first stages of direct coal liquefaction.

\section{Scope:}

1. Importance of Hydrogen Donors in the coal

Study the conversion of Argonne Premium coals in tetralin and 2-tbutyltetralin and compare the following: conversion to soluble products and product composition. Hydrogen donated by both solvents will be measured by gas chromatography and the same technique will be used to establish the amount of dealkylation of 2-t-butyltetralin. Reactions will be performed at several different temperatures for varying amounts of time. 
PRESENT WORK:

Experimental: Coal Conversions using 2-t-Butyltetral in

The donor solvents used, 2-t-Butyltetralin and tetralin were each in excess of $99 \%$ purity. Their purity was measured by gas chromatography. The 2-t-butyltetralin was synthesized ${ }^{1,2}$ and tetralin was purchased from Aldrich.

Parallel liquefaction reactions of tetralin and 2-tbutyltetralin with Argonne Premium samples of Ill \#6 coals were carried out under nitrogen pressure, at $350^{\circ} \mathrm{C}$ for 10 minutes (1 atm. $\mathrm{N}_{2}$ pressure at room temperature). The coal and thimbles used for soxhlet extraction were dried at $110^{\circ} \mathrm{C}$ in a vacuum oven to constant weight. The solvents used were stored under nitrogen.

Table 1 shows the solvent to coal ratios used in liquefaction reactions and their conversions to pyridine solubles. Each Iiquefaction experiment was carried out using two tubing bombs under identical conditions and dry nitrogen atmosphere. For each tubing bomb, a $2: 1$ and a $4: 1$ tetralin to coal weight ratio was used. An equivalent number of moles of 2-t-butyltetralin was used for each parallel reaction.

Within an hour of charging the bombs, the reactors were plunged into the previously heated and fluidized sandbath and shaken at 250 cycles per minute. The time temperature profile was measured using an iron constantan thermocouple attached to the 
reactors. ${ }^{3}$ After the reaction, the reactors were quickly cooled in an ice water bath.

The contents of each reactor was washed out with pyridine into a beaker. A weighed amount of the internal standard was added and thoroughly mixed using a magnetic stirrer. Less than $1 \%$ of each pyridine-coal mixture was filtered through a $0.45 \mu \mathrm{m}$ millipore filter and analyzed by G.C. A Hewlett Packard Model 5880A gas chromatograph equipped with a flame ionization detector was used. The column used was a 15 meter AT-5 capillary column (polydimethydiphenyl (5\%) siloxanes) of $0.25 \mathrm{~mm}$ I.D. and $0.45 \mu \mathrm{m}$ film thickness. The G.C. conditions were as follows: 1)carrier gas and flow rate: He, $0.66 \mathrm{ml} / \mathrm{min})$; oven temperature: $\left(100^{\circ} \mathrm{C}\right.$ for $1 \mathrm{~min}$. , programmed at $3^{\circ} \mathrm{C} / \mathrm{min}$. to $\left.130^{\circ} \mathrm{C}(6 \mathrm{~min}) ; 3\right)$ injection port temperature: $250^{\circ} \mathrm{C} 4$ ) detector temperature: $275^{\circ} \mathrm{C}$ 5) split ratio 130:1. Yields of naphthalene and 2-t-butylnaphthalene, as a result of hydrogen transfer from the donor solvents are reported in Table 2. Dealkylation of 2-t-butyltetralin and the hydrogen transferred per dry ash freo coal are included in Table 2.

The reaction products were sohlet extracted with pyridine in a dry nitrogen atmosphere. When extraction was complete, each pyridine soluble portion was rotory evaporated and vacuum dried to constant weight. The percent pyridine soluble coal on a daf basis was calculated based on the amount of dried pyridine extracts and dried coal residue (Table $1 \mathrm{~A}$ ). The mass balance of the coal, the solvents used and the overall mass balance are included (Table 1B). 
Results and Discussion

This work. was done to determine the importance of internal hydrogen donation as distinct from external hydrogen donation for coal depolymerization coal during liquefaction. In addition, the effects of the amounts of reactant in a tubing bomb and the solvent to coal ratio on conversion are being determined. The first four entries in Table $1 \mathrm{~A}$ are conversions of Ill\#6 coal to pyridine solubles using $22 \mathrm{ml}$ tubing bombs. In the same size reaction vessels and similar solvent to coal ratios, increased reactant amounts lead to increased conversion. The $31 \%$ and $20 \%$ conversions based on the residue (entries 1 and 2 of Table $1 \mathrm{~A}$ ) indicate mixing problems using small reactant sizes in too large bombs. A recent publication by Vlieger and coworkers ${ }^{5}$ showed that conversion to THF solubles varied with the amount of material in the autoclave due to mixing effects. Lower conversions were observed with smaller amounts of reactant than was found for larger reactant amounts at constant solvent to coal ratio.

Conversion data based on the dried extract and the dried residue are included in Tables $1 A \& 1 B$. Conversions based on the solid residue weight are lower than conversions based on the weight of extract. The 4:1 solvent to coal reactions were done using 30 mL tubing bombs (last two entries of Table 1A \& 1B). Inspection of the pyridine solubles based on the extract, and the solvent and 
coal mass balance indicates solvent incorporation into the coal. Higher conversions are observed using tetralin than with 2-tbutyltetralin as the donor solvent. In the last two entries of Table $1 \mathrm{~A}$ and $1 \mathrm{~B}$, a large increase in solvent incorporation is observed when 2-t-butyltetralin is used as donor solvent. The data for the extract based conversions is obviously wrong in these runs, 106\% conversions being impossible. Solvent retention and incorporation under these conditions are being investigated. The conversion data based on the residue amounts show lower conversions in 2-t-butyltetralin than in tetralin. Since the hydrogen donating abilities of the two solvents are the same, this must be due to the exclusion of the bulky 2-t-butyltetralin from the reacting coal. External hydrogen donation is important in coal depolymerization.

The percent hydrogen transferred to the coal was obtained from the amounts of naphthalene and 2-t-butylnaphthalene formed. Compared to the 2:1 solvent to coal ratio, the hydrogen transferred is reduced by a factor of about 2 for the reactions done with the 4:1 solvent to coal ratio (Table 2). Dealkylation of 2-tbutyltetralin remained fairly constant when 2:1 tetralin to coal ratios were employed (Table 2). However, the amount of dealkylation observed with $4: 1$ tetralin :coal reactions is significantly reduced.

These sets of data indicate enhanced conversions with larger solvent to coal ratios. Conversions to pyridine solubles are always higher when tetralin is used as the donor solvent. Lower conversions are observed when 2-t-butyltetralin is used as the 
donor solvent, probably as a result of steric effects imposed by the 2-t-butyl group which prevents the penetration of 2-tbutyltetralin into the depolymerizing coal. In addition to the large solvent incorporation into the coal extracts when large solvent to coal ratios are used, inadequate mixing of small reactant sizes in large reaction vessels was observed. 


\section{REFERENCES}

1. Whitmore, F.C; James, W.H. J. Am. Chem. Soc. (1943), 65, 2088

2. John W.Larsen, Andrzej Lapucha, Lazarin Lwazarov, and Jewel Amui Quarterly Report DE-FG-2290PC.90304

3. Yamada, O.; Azik, M; and Larsen, J.W. Quarterly Report DE-FG22-87PC79926-9

4. Amui, J. and Larsen, J.W. Quarterly Report DE-FG-22-890PC90304

5. Vlieger, J.; Gelan, J.; Franco, D. and Macjchrowicz, B.; Fuel $(1989), 68,696$. 
Table 1: Effects of scaled up reactants (Argonne premium III\#6 and donor solvent) on conversion to pyridine solubles.

A:

\begin{tabular}{|c|c|c|c|c|c|}
\hline Donor & Solvent & Ill\#6 coal & Solvent:L coal & \% $\mathrm{P}$ & yridine \\
\hline Solvent & $\angle \mathrm{mmol}$ & $\lg$ & ratio. $g / g$ & Soluble & daf coal \\
\hline & & & & $\begin{array}{l}\text { Extract } \\
\text { (Based) }\end{array}$ & $\begin{array}{l}\text { Residue } \\
\text { (Based) }\end{array}$ \\
\hline $\begin{array}{l}\text { Tetralin } \\
2-t-\text { Buty } 1 T^{* *}\end{array}$ & $\begin{array}{l}16.0 \\
16.0\end{array}$ & $\begin{array}{l}1.06 \\
1.07\end{array}$ & $\begin{array}{l}2.0 \\
2.7\end{array}$ & $\begin{array}{l}45 \\
35\end{array}$ & $\begin{array}{l}31 \\
20\end{array}$ \\
\hline $\begin{array}{l}\text { Tetralin } \\
2-t-B u t y l T^{* *}\end{array}$ & $\begin{array}{l}46.0 \\
46.6\end{array}$ & $\begin{array}{l}3.00 \\
3.03\end{array}$ & $\begin{array}{l}2.0 \\
2.9\end{array}$ & $\begin{array}{l}50 \\
41\end{array}$ & $\begin{array}{l}46 \\
32\end{array}$ \\
\hline $\begin{array}{l}\text { Tetralin } \\
2-t-B u t y l T^{*}\end{array}$ & $\begin{array}{l}60.7 \\
60.9\end{array}$ & $\begin{array}{l}2.13 \\
2.12\end{array}$ & $\begin{array}{l}4.0 \\
5.4\end{array}$ & $\begin{array}{l}62 \\
106\end{array}$ & $\begin{array}{l}57 \\
37\end{array}$ \\
\hline
\end{tabular}

$\underline{B:}$

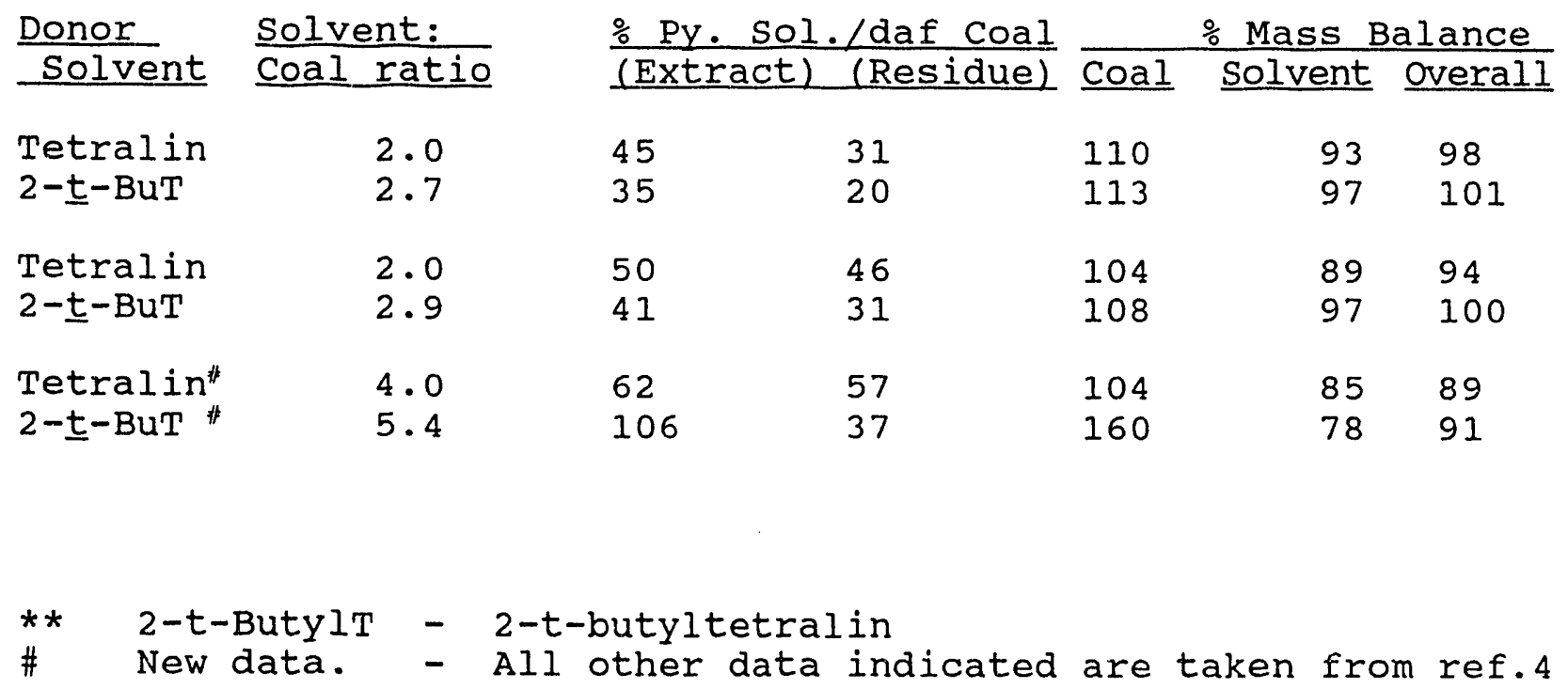


Table 2 Extent of dehydrogenation and dealkylation of donor solvents (G.C). Also included is the $\% \mathrm{H}_{2}$ transferred per daf of III\#6 Coal.

(Product Recovery -mole \%)

Solvent: Tetralin Naph* $^{*} \quad \underline{2-t-B^{*} T^{* *}} \underline{2-t-B u N a p h}{ }^{* * *} \quad: H_{2} /$ daf coal ratio

(Tetralin as solvent)

$\begin{array}{llllll}2.0 & 89.4 & 3.21 & - & - & 0.23 \\ 2.0 & 85.3 & 3.14 & - & - & 0.23 \\ 4.0^{\#} & 83.8 & 1.11 & - & - & 0.15\end{array}$

(2-t-ButylTetralin as solvent)

$\begin{array}{llllll}2.7 & 0.49 & - & 92.7 & 3.80 & 0.26 \\ 2.9 & 0.48 & - & 93.3 & 3.10 & 0.23 \\ 5.4^{\#} & 0.04 & - & 77.1 & 0.78 & 0.11\end{array}$

$\begin{array}{lll}* & \text { Naph } & - \text { Naphthalene } \\ * * & 2-t-B u t y l T & -2-t \text {-butyltetralin } \\ * * * & \text { 2-t-BuNaph }-2-t \text {-butylnaphthalene } \\ \# & \text { New data. } & \text { All other data indicated are taken from ref. } 4\end{array}$ 

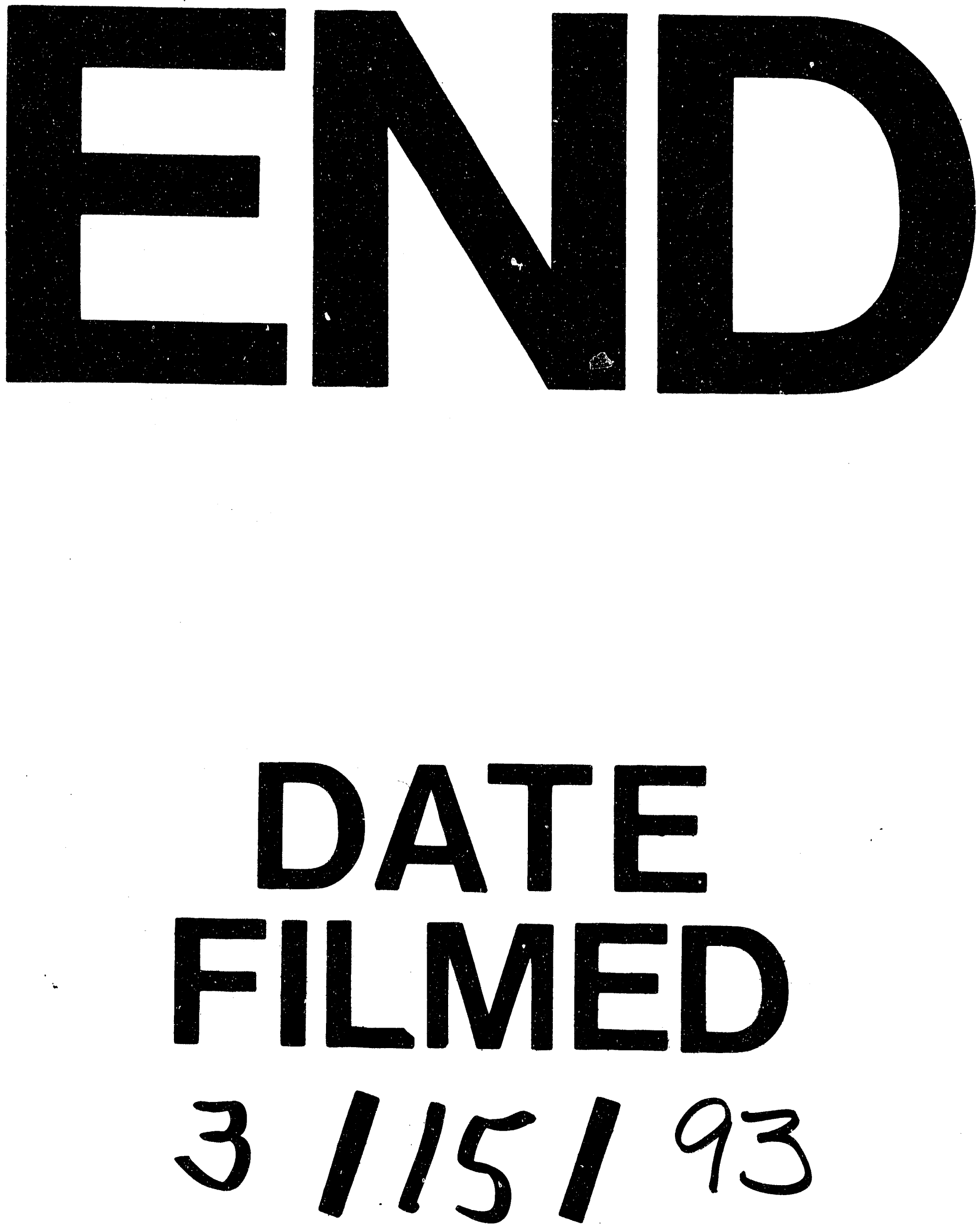
